\title{
Upravljanje vodnim uslugama kao faktor teritorijalne integracije lokalnib jedinica
}

\section{Desanka Sarvan*}

UDK $\quad 35.071 .5: 352 / 353(497.5)$

351.79:352/353(497.5)

Review scientific paper / Pregledni znanstveni rad

Received / primljeno: 17. 3. 2015.

Accepted / prihvaćeno: 20. 7. 2016.

Početkom 21. stoljeća promjene u dostupnosti vodnih resursa i zahtjevi njihove zaštite utjecali su na promjenu radijusa funkcije upravljanja vodnih usluga - od tradicionalno lokalnih poslova one postaju natkomunalna djelatnost. Promjene u upravljanju vodnim uslugama pretpostavljaju integraciju vodnih usluga opskrbe vodom za piće i odvodnje otpadnih voda u jednu uslugu prema načelu upravljanja zahvaćenom vodom od izvorišta do korisnika i od korisnika do upuštanja u okoliš na funkcionalno optimalnom području formiranom prema hidrogeološkoj teritorijalnoj cjelini vodnog podsliva sukladno prirodnim granicama razvođa vodnih područja (uslužno područje). Tako formirana uslužna područja u pravilu obuhvaćaju velik broj lokalnih jedinica te će zahtjevi za efikasnim upravljanjem vodnim

* Desanka Sarvan, viša savjetnica za pravne poslove Istarske županije, Pula (senior legal advisor in Istarska County, Pula, Croatia, e-mail: desanka.sarvan@istra-istria.hr) 
uslugama nužno utjecati na teritorijalnu integraciju lokalnih jedinica na pojedinom uslužnom području.

Ključne riječi: vodne usluge, natkomunalna djelatnost, lokalne jedinice, uslužno područje, podsliv

\section{Uvod}

U povijesti ljudskog društva sve su ljudske zajednice imale potrebu primarno osigurati dovoljne količine vode za piće potrebne za osiguranje života njihovih članova. Od lutajućih ljudskih zajednica lovaca koje su se opskrbljivale vodom nađenom u prirodi te prvih protourbanih naselja, kasnije antičkih gradova Grčke i Rima, srednjovjekovnih gradova - općina, rastućih gradova u 19. stoljeću pa sve do suvremenih megagradova, organizacija opskrbe vodom za piće stanovništva kao esencijalnom potrebom ljudske egzistencije jest izazov s kojim se suočava svaka ljudska zajednica, bez obzira na svoju lokaciju i ustroj društvenih odnosa. Opskrba vodom za piće imala je u povijesti ljudskih zajednica uvijek središnje značenje i dostupnost vodnih resursa odigrala je veliku ulogu u procesu teritorijalizacije ljudskih zajednica jer je osiguravanje dostatnih količina vode za piće bilo središnje pitanje pri planiranju ranih naselja. Voda, vodeni tokovi i izvori bili su presudni za formiranje naselja. Mnogi gradovi osnovani su na mjestima na kojima je bila prirodno osigurana dovoljna količina pitke vode - raspoloživost vode na lokalitetu bila je uvjet za utemeljenje grada. Ne kaže se bez razloga da »vode osnivaju gradove« (aquae condunt urbes). Za osnivanje naselja čovjek je najprije tražio strateški sigurno mjesto, ali uvijek u blizini vode, bez koje nije mogao osigurati trajnost svoga života, opstanak stoke i uzgoj biljaka, tj. kompleksnost života i razvitak zajednice. S vremenom su formirane posebne službe koje su se brinule o opskrbi vodom, primjerice u 5. stoljeću pr.n.e u Ateni je sastavljen institucionalni okvir za održivo upravljanje vodom i pravičnu distribuciju vode te su gradske vlasti odredile jednog javnog službenika (načelnik za fontane) za nadzor i održavanje gradskog sustava opskrbe vodom za piće. To je bila hijerarhijski visoka i važna izborna dužnost, jer je upravljanje vodom bilo od velike važnosti za grad. O vodnim građevinama u carskom Rimu brinula se posebna služba - familia pubblica - grupa od 640 robova čiji su troškovi plaćani iz javnih sredstava i pod vodstvom curatora acquarum. Srednjovjekovni gradski statuti općina - gradova govore o opskrbi vodom za piće i gradskoj higijeni u tim gradskim zajednicama. Održavanje javnih zdenaca i izvora 
vode za piće dužnost je samih građana, dok općinski službenici samo nadziru izvršavanje tih obveza i kažnjavaju građane zanemaruju li tu dužnost. Začetak sustavnog upravljanja vodama i javnim vodnim uslugama datira u drugoj polovici 19. stoljeća, kada se društveni odnosi u svezi s korištenjem vodom uređuju i zakonima o uporabi i korištenju vode, kao i zakonima o mjerama zaštite javnog zdravlja, osnivaju se službe i pravne osobe zadužene za razvoj i upravljanje vodnim uslugama (Sarvan, 2014, str. 131-140).

Upravljanje vodnim uslugama tradicionalno je i povijesno funkcija javnog sektora - ovisno o tradicionalnom povijesnom društvenom razvoju - lokalne, regionalne ili državne razine. ${ }^{1} \mathrm{U}$ većini država u svijetu, a posebno u Europi, vodne usluge povijesno su i tradicionalno u djelokrugu JLS, iako ima primjera država u svijetu različite pravne tradicije u kojima su te usluge u djelokrugu regionalne ili državne razine, ili u različitim kombinacijama tih razina javnih vlasti (Afrika, Latinska Amerika).

Slika 1. Razine javnih vlasti u upravljanju vodnim uslugama

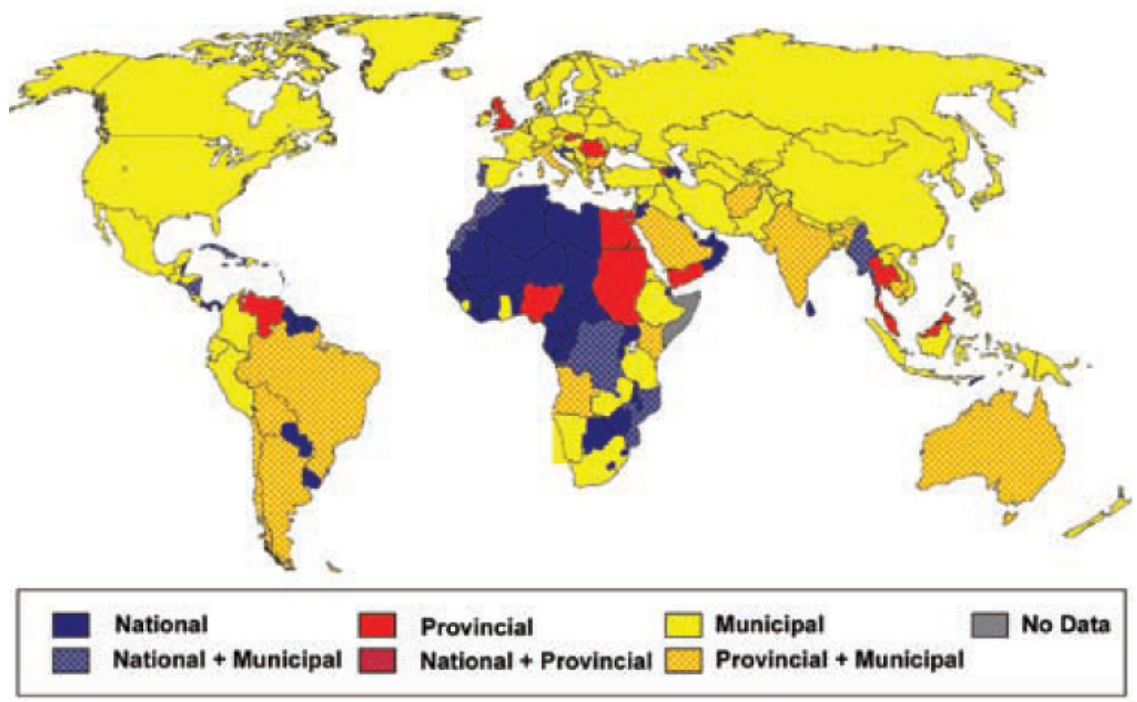

Izvor: Van Ginneken \& Kingdom, 2008., str. 4.

${ }^{1}$ Vodne usluge su usluge javne vodoopskrbe i javne odvodnje. Javna vodoopskrba je djelatnost zahvaćanja podzemnih i površinskih voda namijenjenih ljudskoj potrošnji i njihova kondicioniranja te isporuke do krajnjega korisnika ili do drugoga isporučitelja vodne usluge, ako se ti poslovi obavljaju putem građevina javne vodoopskrbe, te upravljanje tim građevinama ili na drugi propisani način (cisternama, vodonoscima i sl.). Javna odvodnja je 
Krajem 20. i početkom 21. stoljeća globalna kriza vode uzrokovana klimatskim promjenama, porastom broja svjetskog stanovništva, globalnom urbanizacijom i implementacijom politike novog javnog menadžmenta donosi promjene u načinu upravljanja vodnim uslugama.

Prvo, klimatske promjene posljedica su antropogenih utjecaja otpuštanja u atmosferu stakleničkih plinova i/ili njihovih prethodnika (greenbouse gas) zbog korištenja fosilnih goriva te povećanja globalne temperature u prošlom stoljeću za $0,7^{\circ} \mathrm{C}$, i taj se trend nastavlja i ubrzava. Izravna posljedica klimatskih promjena je ubrzavanje globalnog hidrološkog procesa vode, koji ima povratno negativno djelovanje na globalnu klimu i njezine daljnje promjene (UNESCO, 2009, str. 200). Specifične promjene vodnih resursa i hidrološkog ciklusa zbog klimatskih promjena mogu biti promjene u površinskim tijekovima vode, povećana mogućnost poplava, povećani gubici vode evaporacijom zbog povećanja temperature i povećane količine vode u atmosferi, promjene u sezonskom ili vremenskom tijeku vodenih tokova naročito u vodnim područjima koje se alimentiraju vodom od otapanja snijega, promjene tijeka vode iz ledenjaka tijekom njihova povlačenja, porast snježnih padalina i permafrosta, nedovoljno punjenje jezera, močvara i podzemnih vodonosnika zbog varijabilnosti količine atmosferskih padalina te izmjena sastava tla (salinitet i vlažnost), dezertifikacija, degradacija tla i suša, otapanje ledenjaka te porast razine svjetskih mora i opadanje razine vodenih ploča (UNDP, 2006, str. 159).

Drugo, broj svjetskog stanovništva i njegova koncentracija u nerazvijenim zemljama u stalnom je porastu, a predviđa se da će se taj trend nastaviti do kraja 21. stoljeća. Porast broja stanovnika na Zemlji povećava potrebe za vodom za proizvodnju hrane, energije, industrijskih proizvoda i vode za piće, čime se povećava pritisak na korištenje postojećih vodnih resursa. Kako raste broj stanovnika, globalne potrebe za vodom per capita rastu, kako zbog zadovoljavanja osnovnih potreba tako i zbog određenog načina (stila) života, tj. zadovoljavanja potreba za boljom prehranom, dostupnosti industrijskih proizvoda i komforom. Osim toga, rast broja svjetskog stanovništva utječe na povećano onečišćenje vodnih resursa uporabljenom vodom.

djelatnost skupljanja otpadnih voda, njihova dovođenja do uređaja za pročišćavanje, pročišćavanja i izravnoga ili neizravnoga ispuštanja u površinske vode, obrade mulja koji nastaje u procesu njihova pročišćavanja, ako se ti poslovi obavljaju putem građevina javne odvodnje, te upravljanje tim građevinama; javna odvodnja uključuje i pražnjenje i odvoz otpadnih voda iz septičkih i sabirnih jama (čl. 3/1. t. 28. i 29. Zakona o vodama, NN 153/09, 63/11, 56/13 i $14 / 14)$. 
Treće, globalni proces koncentracije stanovništva u urbanim središtima (urbanizacija) zahtijeva dopremanje sve većih količina vode za zadovoljavanje potreba za vodom za piće sa sve većih udaljenosti kao i pročišćavanje velikih količina visokokoncentriranih sanitarnih voda na relativno malom području urbanog centra. Očekuje se da će polovinom 21. stoljeća sedam od 10 ljudi na planetu, odnosno $70 \%$ svjetske populacije, živjeti u urbanim područjima te se stoga 21. stoljeće naziva »urbani milenij«. Još 1950. na svijetu su bila samo dva grada (megagradovi) koja su brojem stanovnika premašivala 10 milijuna stanovnika, a već 2010. bila su 23 grada koja su brojem stanovnika premašivala 10 milijuna stanovnika. Očekuje se da će 2025. biti 39 gradova s preko 10 milijuna stanovnika te da će do 2030 . porast urbanog stanovništva u nerazvijenim zemljama biti 3,9 milijarde i milijardu stanovnika u razvijenim zemljama (UNESCO, 2012, str. 64).

Četvrto, posljednjih desetljeća upravljanje vodnim uslugama prolazi kroz proces pomicanja od političkih institucija prema ekonomskim, slijedeći proces ekonomske valorizacije resursa vode i njihove nedostatnosti te tendencije da se upravljanje vodnim uslugama podvrgne zakonima tržišta umjesto upravljanju od javnog sektora. Do kasnih 70-ih godina 20. stoljeća javna poduzeća bila su uobičajeni oblik upravljanja javnim vodnim uslugama, kako u razvijenim tako i u nerazvijenim zemljama, ali je njihova neefikasnost pridonijela implementaciji privatizacije početkom 80 -ih s ciljevima porasta prihoda države, promicanja ekonomske efikasnosti, smanjenja utjecaja javnih vlasti u ekonomiji, promicanja različitih oblika vlasništva, uvođenja tržišnog nadmetanja i podvrgavanja javnih poduzeća tržišnoj disciplini. Načelno, privatizacija nije inkompatibilna s vodnim uslugama, ali na tržištu s ograničenom mogućnosti nadmetanja i proizvodom koji je temeljan za ljudsku dobrobit važna je uloga regulacijskih tijela koja moraju osigurati da isporučitelji upravljaju vodnim uslugama na način koji osigurava i efikasnost i jednakost u opskrbi (Fitzmaurice, 2007, str. 576). Implementacija politike novog javnog menadžmenta u sektoru vodnih usluga nije polučila svugdje uspješne rezultate jer je dovela do nejednakosti u opskrbi vodnim uslugama - vodne usluge uskraćene su siromašnim slojevima stanovništva koji nisu sposobni plaćati cijenu usluga i to je bio uzrok mnogih od najintenzivnijih društvenih sukoba današnjice (primjerice u Boliviji u gradovima Cochabamba, Cordoba i La Paz te i u gradovima Buenos Aires, Manila, Delhi, Tamil Nadu, Johanesburg, Mexico City, Cancun i dr.) (Sarvan, 2014, str. 631). 


\section{Primjena radijusa funkcije vodnih usluga}

Kao odgovor na izazove globalne krize vode znanost smatra politiku cjelovitog i međusektorskog upravljanja vodama, tj. integralno upravljanje vodama (integrated water resources managment), koja kao podsustav pretpostavlja integralno upravljanje vodnim uslugama (integrated urban water managment). ${ }^{2}$

Slika 2. Medusektorska integracija upravlianja vodama

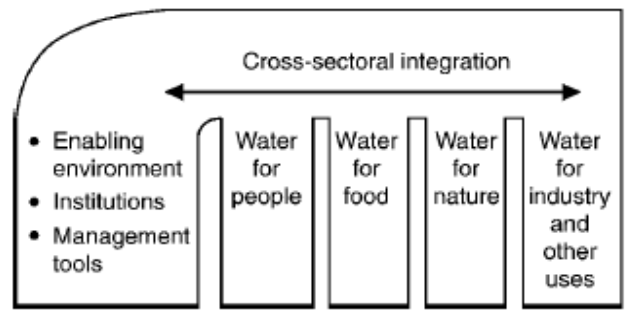

Izvor: Jùnch-Clausen \& Fugl, 2001, str. 503.

Integralno upravljanje javnim uslugama pretpostavlja horizontalnu i vertikalnu integraciju sustava upravljanja vodnim uslugama. Horizontalna integracija pretpostavlja teritorijalnu, institucionalnu i financijsku integraciju sustava vodnih usluga utemeljenu na uslužnim područjima kao funkcionalnim teritorijalnim cjelinama formiranim prema hidrogeološkim obilježjima područja, upravljanje uslužnim područjem od jednog specijaliziranog isporučitelja vodnih usluga i ustanovljenje jedinstvene tarife cijena na uslužnom području prema prosječnim troškovima proizvodnje tih usluga na tom području. Vertikalna integracija sustava javnih vodnih usluga pretpostavlja ustanovljenje nezavisnog regulatora na razini države.

Promjene u upravljanju vodnim uslugama prvenstveno pretpostavljaju funkcionalnu integraciju vodnih usluga opskrbe vodom za piće i odvodnje otpadnih voda u jednu uslugu s ciljem zaštite vodnih resursa prema načelu upravljanja zahvaćenom vodom od izvorišta do korisnika i od korisnika do upuštanja u okoliš, na funkcionalno optimalnom području koje omogućava

2 Od upravljanja javnim vodnim uslugama potrebno je razlikovati poslove upravljanja vodama koji obuhvaćaju osobito poslove u nadležnosti države: pripremu podloga za kreiranje vodne politike, pripremu programa, planova i drugih akata koji čine osnovu za osiguravanje dovoljnih količina odgovarajuće vode za različite potrebe, zaštitu voda od onečišćenja, uređenje vodotoka i drugih voda i zaštitu od štetnoga djelovanja voda, investitorske i druge poslove kojima se izvršavaju ti programi, planovi, poduzimanje mjera kojima se osigurava racionalno korištenje voda, zaštita voda i zaštita od poplava i drugih oblika štetnoga djelovanja voda. 
ostvarenje cjeline ciklusa zahvaćanja vode iz okoliša i upuštanja pročišćene uporabljene vode u stanju prihvatljivom za okoliš (geohidrološko područje). Posljedica takvog pristupa jest promjena radijusa funkcije vodnih usluga. U okolnostima ograničene dostupnosti prirodnog resursa vode u okolišu, funkcionalno upravljanja vodnim uslugama postaje primarni imperativ u odnosu na teritorijalnu organizaciju njihova obavljanja. Tako svjedočimo promjeni akcijskog radijusa ove službe u vezi s promjenama standarda vodnih usluga uvjetovanog razvitkom društva i same službe, koji će, s obzirom na primarnu važnost vodnih usluga za građane i gospodarstvo, zasigurno utjecati i na izmjenu područja lokalnih jedinica ili izdvajanje te djelatnosti u specijalizirane lokalne jedinice.

U literaturi se ističe da je veličina lokalne zajednice određena time što neke potrebe moraju biti podmirene unutar određenog radijusa, jer se lokalne jedinice ne mogu formirati mimo prirodnih uvjeta zadane sredine sukladno tehnološkom razvoju određenog povijesnog trenutka. Geografski faktor koji utječe na formiranje lokalnih jedinica dolazi do izražaja inter alia kroz hidrografsku mrežu te je zapaženo da se granice novih lokalnih jedinica mogu formirati prema granicama razvođa i gorskih grebena. Porast cijene usluga zbog sve savršenije tehnologije pojedinih službi i većih postavljenih standarda njihove izvedbe vodi k povezivanju većeg teritorija i većeg broja ljudi kako bi se osigurala i veća sredstva za podmirenje njihova obavljanja. U tom smislu, širi stupanj lokalnih jedinica mogao bi preuzeti funkcije planiranja, koordinacije i obavljanja funkcija širokog raspona, dok bi se lokalne službe povjerile nižem stupnju (Perko-Šeparović \& Hrženjak, 1998, str. 6797). Druga je opcija stvaranje specijalnih lokalnih jedinica prema izvršavanju funkcije vodnih usluga koja je prisutna u engleskoj tradiciji (Velika Britanija, Australija), iako u svjetskim razmjerima prevladava tip lokalnih jedinica koje u svojim okvirima integriraju sve ili većinu lokalnih službi, dok se tip specijalnih jedinica pojavljuje ipak kao iznimka i nigdje nije zastupljen kao isključivi način obavljanja lokalnih upravnih službi, pri čemu je osnovni razlog za formiranje i postojanje specijalnih jedinica bio odlučan geografski moment određivanja najprikladnijeg područja za stanovništvo i najefikasnijeg za upravljanje (Perko-Šeparović \& Hrženjak, 1998, str. 110).

\section{Teritorijalna integracija vodnih usluga}

Integralno upravljanje vodnim uslugama temelji se na upravljanju vodnim uslugama na razini teritorijalnih tehnoloških funkcionalnih cjelina koje osiguravaju zaštitu i održivo korištenje vodnih resursa, a koji pripadaju 
jednom podslivu prema prirodnim granicama razvođa vodnih područja (uslužno područje). Podsliv označava površinu zemljišta s kojeg se sve površinsko otjecanje kroz niz potoka, rijeka i eventualno jezera slijeva u određenu točku na nekom vodotoku (obično u jezero ili ušće u drugu rijeku) (čl. 2/1/t. 14. Okvirne direktive o vodama). Formiranjem uslužnih područja postiže se horizontalna integracija sustava upravljanja vodnim uslugama poštovanjem hidrografskih obilježja područja te jedinstvo i kohezija vodnog režima.

\subsection{Slovenija}

Nacionalni program upravljanja vodama Republike Slovenije i operativni program vodoopskrbe još je u 2004. kao ciljeve za osiguranje dovoljnih količina vode naznačio integraciju ciklusa opskrbe vodom (izvor vode, opskrba vodom za piće i odvajanje i čišćenje otpadnih voda), racionalizaciju isporučitelja javnih usluga opskrbe vodom za piće i objedinjavanje u funkcionalno zaokružene sustave (Nacionalni program, 2004). Kako voda ima nesporno strateški značaj i povezujuću ulogu u prostoru, pri razdiobi Slovenije na pokrajine potrebno je, koliko je moguće, poštovati načelo integralnog upravljanja vodama koje je temelj europske politike voda.

Usporedba između granica općina i hidrografske podjele Slovenije pokazuje da se općinske granice ne poklapaju s granicama hidrografskih bazena u odnosu na granice razvođa. Ta se činjenica iskazuje kao problem u usklađivanju lokalnih interesa u vodnom sektoru između općina (na primjer opskrba pitkom vodom, zagađenje voda, voda za navodnjavanje). Usitnjenost i nedostatni financijski i kadrovski kapaciteti općina zapreka su izvršavanju obveza općina u upravljanju vodama te bi regionalizacija morala obuhvatiti pitanje uloge općina na tom području jer je sada prevelik broj općina čije se granice ne poklapaju s granicama razvođa te otežanog upravljanja vodama u okviru cjelovitih hidroloških jedinica (Mikoš, 2011, str. 524). U navedenoj reformi regije bi morale preuzeti i određene poslove upravljanja vodama koje su sada u nadležnosti države. Aktualna podjela na dvanaest statističkih regija nije primjerena integralnom upravljanju vodama, previše je fragmentirana i ne podudara se s postojećim granicama riječnih slivova, dok se prijedlog formiranja šest regija ne podudara u potpunosti s postojećim vodnim površinama te najviše odstupa na području rijeke Drave. Stoga se kao optimalan smatra prijedlog o formiranju triju regija koje bi imale najprikladniju hidrografsku podlogu (s izuzetkom Savinje i Sutle) i dovoljni financijski kapacitet te bi bile dovoljno 
velike i za osiguranje stabilne regionalne pokrivenosti vodnih resursa za opskrbu vodom za piće, kao i pojedinih poslova upravljanja vodama kao što je uporaba vode za navodnjavanje, zaštita od poplava i korištenje vodnih snaga sa gospodarskog gledišta i ima većeg opravdanja od podjele na šest regija. Ističe se da integrirano upravljanje vodama na razini riječnog sliva (vodene površine) treba biti jedno od stručnih polazišta u određivanju broja i lokacije područja regija.

\subsection{Italija}

Implementacija sustava integralnog upravljanja vodnim uslugama (integrated urban water managment, sistema idrico integrato) započeta je u Republici Italiji donošenjem Zakona br. 36/94 5. siječnja 1996. (Legge Galli). Sustav integriranih vodnih usluga definiran je kao cjelina javnih usluga crpljenja, proizvodnje i distribucije vode za civilnu uporabu, odvodnje i pročišćavanja otpadnih voda, koji se temelji na cjelovitom upravljanju na načelima efikasnosti, efektivnosti i ekonomičnosti. Temeljno je načelo da sve površinske i podzemne vode predstavljaju resurs koji mora biti očuvan i mora biti upotrebljavan prema načelima solidarnosti, da uporaba vode mora biti usmjerena na štednju i obnovu resursa te da je uporaba vode za ljudske potrebe od prioritetnog značaja. Ostvaruje se kroz tri temeljne postavke: a) nacionalni teritorij podijeljen je na uslužna područja (ambito territoriale ottimale - ATO, tj. optimalno područje) i u svakome od njih jedan upravitelj obavlja vodne usluge u cijelom ciklusu, tj. integrirane vodne usluge, b) tarifa vodnih usluga od davanja na koja utječu političko-socijalne odluke transformira se u stvarnu cijenu koštanja vodnih usluga, c) izgradnja sustava prelazi iz javnog financiranja u samofinaciranje koje se temelji na tarifi cijena vodnih usluga.

Granice uslužnih područja određene su temeljem sljedećih kriterija: a) pripadnost cjelini vodnog sliva ili vodnog podsliva, ili vodnim slivovima koji se dotiču, vodeći računa o planovima slivnog područja, utvrđivanju vodnih resursa i određivanja mjesta njihova korištenja, u korist zainteresiranih naseljenih mjesta, b) jedinstvo upravljanja sustavom te sprječavanje vertikalne fragmentacije upravljanja, c) odgovarajuće veličine za upravljanje sustavom, određene prema fizičkim, demografskim i tehničkim parametrima te temeljem postojećih upravno-političkih jedinica. ${ }^{3} \mathrm{U}$

${ }^{3}$ Art. 8. 1. Legge RI br. 34/96., Art. 147. DLvo 152/2006. Promjenu granica optimalnih područja radi optimalizacije upravljanja sustavom ili radi usklađenja samih optimalnih 
formiranju uslužnih područja kriterij određivanja veličine prema jedinstvu vodnog sliva odnosno podsliva samo je djelomično poštovan te je pretežno prihvaćen kriterij njihova formiranja prema administrativnim granicama područja provincija. ${ }^{4}$ Do 2008. oko 8.100 lokalnih jedinica (općina) u 19 talijanskih regija koje obuhvaćaju 110 provincija koje su bile obvezne formirati uslužna područja objedinjeno je u 92 optimalna područja te se broj uslužnih područja približno poklapa s brojem provincija kao lokalnih jedinica drugog stupnja.

\subsection{Hrvatska}

Strategija upravljanja vodama (NN 91/08, dalje: Strategija) u Republici Hrvatskoj upozorila je posebno na usitnjenost i neracionalnost sustava koje najvećim dijelom proistječu iz odredbi Zakona o komunalnom gospodarstvu, kojim nije uspostavljen koncept javne vodoopskrbe i odvodnje kao nadkomunalnih djelatnosti, što pretpostavlja jedinstven tehničkotehnološki sustav (od izvorišta do korisnika i od korisnika do ispusta u prijamnik) i obuhvaća više JLS. Strategija je naglasila da je u području javne vodoopskrbe cilj uspostavljanje uslužnih područja odnosno uspostava regionalnih vodoopskrbnih sustava, a u području zaštite voda cilj je uspostava aglomeracija kao jedinstvenih cjelina radi zaštite voda.

Strategija je upozorila da komunalnu djelatnost opskrbe vodom za piće i odvodnje otpadnih voda u Republici Hrvatskoj obavlja velik broj isporučitelja komunalnih usluga vrlo različitih stupnjeva uspješnosti i uspostavljenih standarda usluga te da postoji neujednačenost razine usluga. U ko-

područja s regionalnim razvojem predlaže skupština regije poglavarstvu regije (Consiglio regionale), koje donosi odluku uz mišljenje uprave provincija i uprave vodnog sliva.

${ }^{4}$ Podaci iz izvješća Comitato per la vigilanza sull' uso delle risorse idrice za 2008. pokazuju da je od 19 regija koje su uredile tu pravnu materiju pet regija utvrdilo jedno jedinstveno uslužno područje za područje regije, šest regija je odredilo uslužna područja na temelju granica provincija, drugih šest je granice uslužnih područja odredilo vrlo slično granicama provincija, a samo su dvije regije odabrale kriterije formiranja uslužnih područja uključivši različite općine u odnosu na njibovu pripadnost administrativnim granicama provincija. Većina uslužnih područja obuhvaća između 250.000 do 400.000 stanovnika (26), slijede ona od 400.000 do 750.000 stanovnika (24) te 20 uslužnih područja od 100.000 do 250.000 stanovnika, jedno s populacijom do 100.000 , sedam sa od 750.000 do 1.000 .000 stanovnika, devet sa 1.000 .000 do 2.000 .000 stanovnika te pet sa više od 2.000 .000 stanovnika. U odnosu prema broju obubvaćenih općina u pojedinom uslužnom području, najveći broj općina (377) obuhvaća jedinstveno uslužno područje ATO Unico Sardegna, dok jednu općinu obuhvaća uslužno područje ATO Citta di Milano. Najviše je uslužnih područja s brojem od jedne do 50 općina (37 uslužnih područja) te od 51 do 100 općina (29 uslužnih područja). 
munalnoj vodnoj djelatnosti u Republici Hrvatskoj u potpunosti dominira javni sektor (komunalna društva, komunalne ustanove i vlastiti pogoni jedinica lokalne samouprave), osim koncesije za pročišćavanje otpadnih voda po modelu BOT u Zagrebu. U javnoj vodoopskrbi 2007. poslovalo je 98 komunalnih društava (uključujući i jednu ustanovu) i 89 u odvodnji i pročišćavanju otpadnih voda, od kojih su mnoga obavljala i jednu i drugu djelatnost. Djelatnost se obavljala na 127 uslužnih područja koja su pokrivala samo dio od 550 gradova i općina (odnosno 6.759 naselja). Osim toga, stanje javne vodoopskrbe u Hrvatskoj analizira se i prati na razini 68 tzv. »vodoopskrbnih zona«, odnosno područja na kojima je moguće organizirati javnu vodoopskrbu u širem smislu, koje su određene pretežito temeljem tehničke analize postojećeg stanja i planova razvoja vodoopskrbe. Prosječna vodoopskrbna zona ima 65.000 stanovnika (u usporedbi s potrošnjom u 2009.) i godišnju proizvodnju vode od oko 3,8 milijuna $\mathrm{m}^{3}$ (Plan, 2010, str. 12).

Pokušaj objedinjavanja obavljanja vodnih usluga na širem području predlagan je 2009. Prijedlogom zakona o vodama (PZE 214), kojim je bilo predviđeno formiranje zajednice uslužnih područja kao novog oblika obveznog udruživanja JLS na koje bi se prenijele ovlasti i nadležnosti JLS u djelatnostima vodnih usluga. Prema navedenom Prijedlogu, ovlasti zajednice, kao posebne pravne osobe, trebale su biti ove: a) može odrediti da se uz cijenu javne vodoopskrbe, cijenu javne odvodnje otpadnih voda i cijenu pročišćavanja plaća i naknada za razvoj, b) kada su radi zaštite izvorišta, u zonama sanitarne zaštite, potrebna posebna povećana ulaganja u građevine javne vodoopskrbe i/ili građevine javne odvodnje otpadnih voda, zajednica može uvesti naknadu za razvoj na uslužnom području radi podmirenja tih potreba, c) donose odluke o obračunu i naplati naknade za razvoj na uslužnim područjima gdje se ta naknada naplaćuje. Te su zajednice zamišljene s jedne strane kao jedinstvena javna vlast te s druge strane kao udruge JLS na uslužnom području. Kako pravni status tih subjekata nije definiran, već je to trebalo biti učinjeno uredbom Vlade, koja je trebala biti naknadno donesena, od prijedloga za osnivanjem zajednica kao posebnih pravnih osoba koje bi obavljale određene ovlasti iz djelokruga JLS u djelatnostima javne vodoopskrbe i javne odvodnje se odustalo te su novim Zakonom poslovi upravljanja vodnim uslugama ipak ostavljeni u izvornoj nadležnosti JLS (čl. 196/3 ZoV).

Novi Zakon o vodama (NN 153/09, 63/11, 130/11, 56/13 i 14/14, dalje: $\mathrm{ZoV})$ definirao je vodoopskrbno područje kao osnovnu jedinicu za obavljanje djelatnosti javne vodoopskrbe, a za obavljanje djelatnosti javne odvodnje aglomeraciju, s time da uslužno područje obuhvaća jedno ili više 
vodoopskrbnih područja i jednu ili više aglomeracija. Uslužna područja su funkcionalne teritorijalne cjeline koje se uspostavljaju radi osiguranja tehničkog i tehnološkog jedinstva građevina javne vodoopskrbe od izvorišta do krajnjega korisnika, tehničkog i tehnološkog jedinstva građevina javne odvodnje od mjesta ispuštanja do prirodnoga prijamnika, isporuke vode namijenjene ljudskoj potrošnji od najmanje dva milijuna $\mathrm{m}^{3}$ godišnje te većeg stupnja učinkovitosti, ekonomičnosti poslovanja i socijalne prihvatljivosti cijena vodnih usluga. Iznimno, uslužno područje može se uspostaviti i ako nije ispunjena pretpostavka isporuke vode namijenjene ljudskoj potrošnji od najmanje dva milijuna $\mathrm{m}^{3}$ godišnje, gdje su zemljopisne značajke područja takve da nije moguće ostvariti tehničko-tehnološko povezivanje građevina javne vodoopskrbe odnosno javne odvodnje (čl. 199/1. i 2. ZoV). Cilj je uspostavljanje uslužnih područja, odnosno uspostava regionalnih vodoopskrbnih sustava, a u području zaštite voda cilj je uspostava aglomeracija kao jedinstvenih cjelina sa svrhom zaštite voda. Formiranje distribucijskih područja kao tehnološko-ekonomskih cjelina potrebno je radi ostvarenja integralnog upravljanja vodnim uslugama koje se temelji na sljedećim aktivnostima: a) na svakom distribucijskom području osnovat će se po jedno komunalno društvo i propisat će se jedinstvena cijena vode te provesti reorganizacija i optimalizacija (okrupnjavanje) komunalnih društava koje će rezultirati znatno manjim brojem društava u usporedbi s trenutačnim stanjem, b) unapređenje učinkovitosti postojećih vodoopskrbnih sustava postići će se njihovim uključivanjem u regionalne sustave s mogućnošću dopreme vode iz više smjerova (slivova), c) uvođenje ekonomske cijene vode uz poštovanje temeljnog načela "potrošač plaća provest će se tehnološkom integracijom sustava i uspostavom distribucijskih područja s jedinstvenom cijenom vode.

U Republici Hrvatskoj formirano je 20 uslužnih područja i njihove se granice ne poklapaju u svakom slučaju s administrativnim granicama općina i gradova odnosno županija, već su određene prema tehnološkoj funkcionalnoj cjelini djelatnosti. ${ }^{5}$ Granice uslužnih područja u velikom se broju podudaraju s granicama županija u Hrvatskoj i predstavljaju vanjske granice JLS koje graniče sa susjednim uslužnim područjem, osim ako podzakonskim aktom nije drukčije određeno, a kada su u uslužno područje uključena pojedina naselja iz gradova i općina, tada vanjska granica tih naselja čini granicu uslužnog područja. Granica između uslužnih područja temelji se na službenoj evidenciji prostornih jedinica iz Središnjeg registra

${ }^{5}$ Na temelju čl. 199/3. ZoV Vlada Republike Hrvatske donijela je Uredbu o uslužnim područjima (NN 67/14). 
prostornih jedinica koji se vodi u Državnoj geodetskoj upravi, sa stanjem na dan 31. prosinca 2013. (čl. 23. Uredbe). Pojedina uslužna područja obuhvaćaju sve gradove i općine u pojedinoj županiji (uslužna područja: 1. Međimurska županija, 2. Varaždinska županija, 12. Istarska županija i 10. Požeško-slavonska županija) ili sve gradove i općine u dvije županije (uslužno područje 4. Bjelovarsko-bilogorska i Koprivničko-križevačka županija), dok druga obuhvaćaju gradove i općine u pojedinim županijama, prema njihovu položaju u odnosu prema funkcionalno-tehnološkoj cjelini obavljanja vodnih usluga na uslužnom području.

ZoV je propisao prethodni proces savjetovanja sa JLS i isporučiteljima (čl. 199/4.) prije određivanja uslužnih područja, koji je sveden na dvotjedno savjetovanje sa zainteresiranom javnošću o Nacrtu prijedloga uredbe o uslužnim područjima od dana 14. veljače 2014. na internetskim stranicama Ministarstva poljoprivrede. Formiranje uslužnih područja nije prošlo bez kritika javnosti o izabranom modelu okrupnjavanja uslužnih područja koja se gotovo preklapaju sa županijama. Primjedbe su bile da bi umjesto toga podjela vodnih poduzeća na području RH trebala biti izvršena prema efikasnosti pružanja vodnih usluga, uvažavajući prostorne i druge zakoni-

Slika 3. Uslužna područja u Hrvatskoj

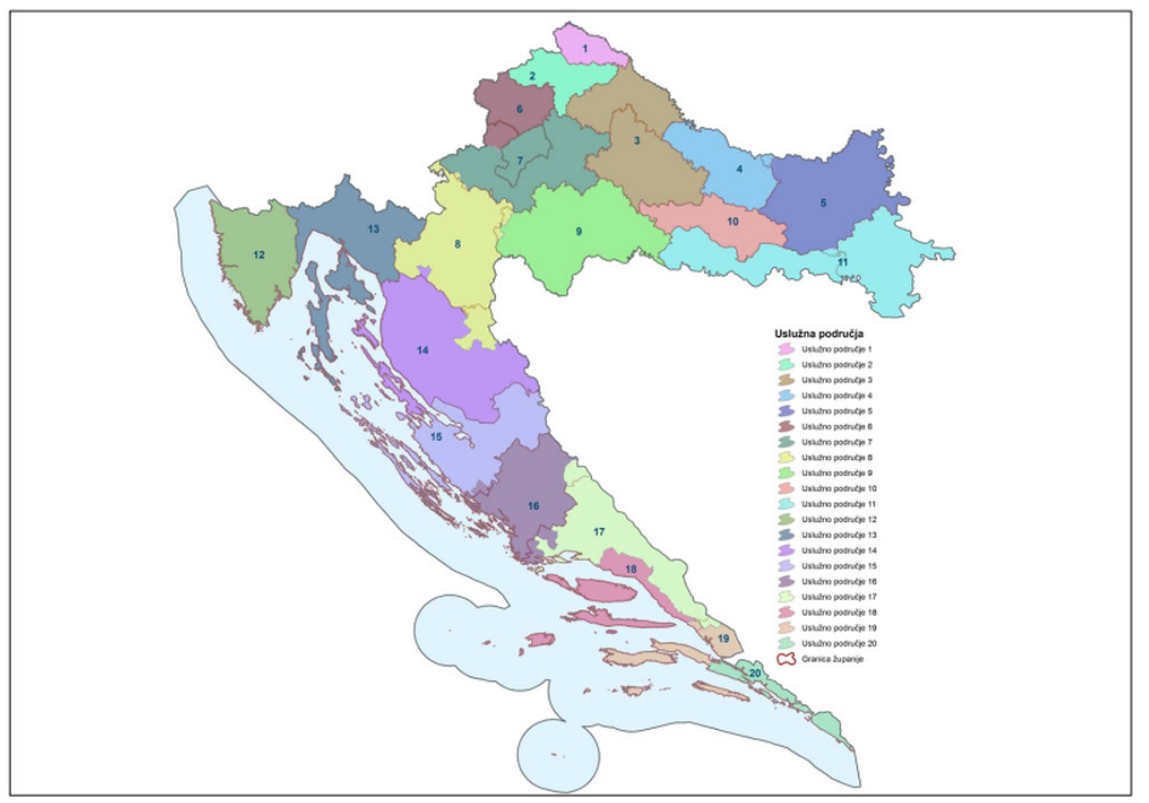

Izvor: Uredba o uslužnim područjima, NN 67/14 
tosti. Među najglasnijim protivnicima u javnosti su županije koje se dijele na više različitih uslužnih područja (primjerice gotovo svi vodoopskrbni sustavi na prostoru Zagrebačke županije potpadaju pod upravljanje Vodoopskrbe i odvodnje Zagrebačkog holdinga, a nekoliko njih pod uslužno područje Krapinsko-zagorske županije) ili se povezuju s područjem drugih županija (primjerice Bjelovarsko-bilogorska županija i Koprivničko-križevačka županija potpadaju pod jedno zajedničko uslužno područje). Predstavnici tih županija izrazili su strahove da će okrupnjavanje donijeti veliko poskupljenje cijena vodnih usluga, a najznačajnije su zamjerke bile da nije poznato detaljno uređenje izabranog modela upravljanja vodnim poduzećima, tj. kako će JLS sudjelovati u vlasništvu i upravljanju budućim nadkomunalnim vodnim poduzećima.

\section{Osnovna pitanja funkcioniranja uslužnih područja}

Uslužna područja za upravljanje vodnim uslugama obuhvaćaju velik broj lokalnih jedinica - u Italiji uslužna područja obuhvaćaju u prosjeku 88 lokalnih jedinica, prema prijedlogu formiranja uslužnih područja u Sloveniji ona bi morala obuhvaćati od 23 do 70 lokalnih jedinica, dok u Republici Hrvatskoj obuhvaćaju prosječno 28 lokalnih jedinica. Velik broj općina na uslužnim područjima u prvi plan postavlja pitanje njihovih odnosa u procesima odlučivanja.

\subsection{Oblici i načini suradnje i koordinacije općina na uslužnom području}

Oblici i načini suradnje i koordinacije općina na uslužnom području ključno je pitanje upravljanja vodnim uslugama na uslužnom području koje obuhvaća velik broj malih lokalnih jedinica.

Primjerice, u Italiji oblike i načine suradnje općina pojedinog uslužnog područja ovlaštene su propisati regije, ali one moraju organizirati upravu uslužnog područja (Autorità d' ambito) kao strukturu s pravnom osobnosti kojoj su prenesene ovlasti u upravljanju vodnim resursima. ${ }^{6}$ Moguća su

${ }^{6}$ Art. 2. comm. 143. Codice d' Ambiente Repubblica Italia, Dlgs 152/2006. 
dva oblika kooperacije i koordinacije općina na uslužnom području: zaključenje konvencije (ugovora) o suradnji i osnivanje konzorcija.

Prvo, konvenciji o suradnji (convenzione di cooperazione) pristupaju lokalne jedinice radi koordiniranog obavljanja određenih funkcija i usluga u određenom razdoblju te se njome određuju trajanje i oblici suradnje lokalnih jedinica sudionica konvencije, njihovi financijski odnosi i međusobne obveze i jamstva. Konvencije mogu predvidjeti ustroj zajedničkih upravnih tijela u kojima poslove obavljaju službenici iz tijela uprave lokalnih jedinica, kojima se povjerava izvršavanje javnih funkcija u ime lokalnih jedinica koje sudjeluju u konvenciji, kao i delegirati obavljanje tih poslova jednoj od lokalnih zajednica koj"a će te poslove obavljati u ime ostalih sudionika konvencije. Konvencija mora sadržavati: a) ciljeve, b) rok trajanja, c) oblike dogovaranja između lokalnih jedinica sudionica konvencije, d) određenje lokalne jedinice odgovorne za koordinaciju i načine koordinacije, e) ovlast lokalnoj jedinici odgovornoj za koordinaciju radi zaključenja konvencije za upravljanje sustavom integriranih vodnih usluga s odabranim upraviteljem sustava, f) financijske odnose, obveze i jamstva, g) oblike upravljanja sustavom integriranih vodnih usluga, način njegove organizacije, nadzora i kontrole, h) postupak za povjeravanje upravljanja sustavom integriranih vodnih usluga, i) objektivna ekonomska i organizacijska mjerila na temelju kojih se može procijeniti koji se postojeći subjekti koji obavljaju vodne usluge na području sustava mogu zadržati u postojećem obliku.

Drugo, općine na uslužnom području mogu osnovati konzorcij (consorzio) koji je oblik jedinstvenog upravljanja jednom uslugom ili većim brojem usluga i izvršavanja zajedničkih funkcija lokalnih jedinica s pravnom osobnosti. U konzorciju mogu sudjelovati i druge javne jedinice kada je to dopušteno posebnim zakonima. Između istih lokalnih jedinica može se osnovati samo jedan konzorcij za pojedinu djelatnost. Osnovni akt konzorcija je statut kojim se određuje organizacija, naziv i ovlasti tijela konzorcija. Skupštinu konzorcija (assamblea) čine zakonski predstavnici lokalnih jedinica - načelnici, predsjednici ili od njih delegirane osobe, svaki prema odgovornostima sukladno udjelu utvrđenom u konvenciji i statutu. Skupština konzorcija izabire izvršno tijelo (consiglio di amministrazione) i donosi temeljne akte konzorcija prema odredbama statuta konzorcija, kao temeljnog akta.

Lokalne jedinice na uslužnom su području obvezne ustrojiti tijelo upravljanja uslužnim područjem (uprava ushužnog područja) u čijem je djelokrugu organizacija, povjeravanje upravljanja i nadzor upravljanja sustavom integriranih vodnih usluga. Uprava uslužnog područja smatra se formalno ustrojenom zaključenjem konvencije o kooperaciji, odnosno osnivanjem konzorcija između lokalnih jedinica koje pripadaju pojedinom uslužnom 
području. ${ }^{7}$ Troškove funkcioniranja ove operativne strukture, tj. uprave uslužnog područja, koji se iskazuju godišnje, podmiruju lokalne jedinice koje pripadaju uslužnom području, sukladno udjelu pojedine lokalne jedinice u tijelima upravljanja.

U Hrvatskoj je prihvaćen drukčiji koncept. Prijedlogom zakona o vodnim uslugama (u daljnjem tekstu: PZVU), koji je u Republici Hrvatskoj bio u postupku savjetovanja s javnosti od 8. srpnja do 9. rujna 2015., 8 izričito je istaknuto načelo jedno uslužno područje - jedan isporučitelj vodnih usluga (čl. 8/1.) te je propisan postupak i način osnivanja ustanove koja bi u određenom roku morala preuzeti djelatnost svih dosadašnjih isporučitelja vodnih usluga na pojedinom uslužnom području.

\subsection{Institucionalna integracija - upravitelj sustava}

Integralno upravljanje vodnim uslugama pretpostavlja upravljanje uslužnim područjem od jednog specijaliziranog isporučitelja koji obavlja isključivo djelatnosti vodnih usluga, ali ne i druge komunalne ili tržišne gospodarske djelatnosti, koji postaje upravitelj sustava integralnog upravljanja vodnim uslugama. Procesi odabira upravitelja i pravni status upravitelja sustava mogu biti različiti (javni isporučitelj, privatni isporučitelj, trgovačko društvo s mješovitim kapitalom).

Primjerice, u Italiji se upravljanje sustavom integralnih vodnih usluga može povjeriti isporučitelju - upravitelju sustava: a) povjeravanjem obavljanja vodnih usluga trgovačkom društvu u privatnom vlasništvu u postupku javnog natječaja, b) izravnim povjeravanjem obavljanja vodnih usluga trgovačkom društvu u mješovitom vlasništvu uz prethodni javni natječaj za odabir privatnog partnera, c) izravnim povjeravanjem trgovačkom društvu u javnom vlasništvu (in house). Upravljanje sustavom integriranih usluga povjerava se isporučitelju, koji preuzima upravljanje sustavom (gestione) i isporuku vodnih usluga (erogazione) na području cijelog uslužnog područja. ${ }^{9}$ Odnosi između uprave uslužnog područja i upravitelja sustava integri-

${ }^{7}$ Konvencija ili konzorcij oblici su udruživanja lokalnih jedinica radi upravljanja određenim specifičnim uslugama ili za realizaciju određenog projekta, a država i regije mogu propisati oblike obvezne konvencije između lokalnih jedinica i tipske sadržaje konvencije (Art. 30. i 40 TUEL, Dlsg. 267/2000).

${ }^{8}$ https://esavjetovanja.gov.hr/ECon/MainScreen?entityId=1551

9 Iznimke su moguće radi očuvanja oblika i kapaciteta postojećih isporučitelja (gestioni di salvaguardare), pod uvjetom da oni ispunjavaju posebne uvjete osiguravanja efikasnosti, 
ranih vodnih usluga uređuju se konvencijom o povjeravanju upravljanja sustavom (convenzione di affidamento) koju predlaže uprava uslužnog područja i koju moraju prihvatiti regije odnosno autonomne provincije. Konvencija kao ugovorni instrument kojim se definiraju osnovna pitanja upravljanja uslužnim područjem između lokalnih jedinica i upravitelja sustava obuhvaća: a) odabrani pravni oblik upravljanja sustavom, b) vrijeme na koje se povjerava upravljanje sustavom, koje ne može biti dulje od 30 godina, c) obvezu postizanja uravnoteženog ekonomsko-financijskog upravljanja, d) razinu efikasnosti sustava koji će osigurati kontinuitet uporabe, uz obveze održavanja infrastrukture, e) mjerila i načine za primjenu tarifa utvrđenih od uprave uslužnog područja i njihovo godišnje usklađivanje, s posebnim kategorijama korisnika, f) obvezu donošenja povelje o uslugama (carta di servizio), g) obvezu ostvarenja programa upravljanja, h) načine nadzora ispravnosti obavljanja usluga i osiguranja sustava kontrole kvalitete usluga, i) obvezu suradnje s ciljem organizacije i funkcioniranja sustava nadzora koje ostvaruje uprava uslužnog područja tijekom razdoblja u kojem mu je povjereno upravljanje sustavom, 1) obvezu periodičnog izvještavanja uprave uslužnog područja o događajima koji mogu utjecati ili utječu na nepravilno izvršavanje usluga, kao i obvezu prihvaćanja svake inicijative za otklanjanje tih nepravilnosti, $m$ ) obvezu povrata građevina i uređaja sustava integriranih vodnih usluga, nakon isteka razdoblja na koje mu je povjereno upravljanje u stanju funkcionalne sposobnosti, n) financijske garancije i jamstva, o) penale i kazne u slučaju neizvršavanja usluga i uvjete otkazivanja upravljanja sustavom prema načelima civilnog kodeksa, p) načine vrednovanja troškova aktivnosti upravitelja sustava (Art. 151. c 1., DL 152/2006).

Do konca 2009. godine 69 uslužnih područja povjerilo je upravljanje sustavom integriranih vodnih usluga trgovačkim društvima, njima 114, od čega je 58 društava s javnim kapitalom (javni operater), 22 društva s mješovitim kapitalom u kojima je privatni partner odabran u postupku javnog natječaja, 7 društava u cijelosti s privatnim kapitalom te 9 društava s kapitalom koji kotira na burzi, a 18 društava drugih oblika vlasništva. ${ }^{10}$

Unatoč odabiru jednog upravitelja sustava integriranih vodnih usluga, u većini uslužnih područja u mnogima uz upravitelja sustavom još uvijek

efektivnosti i ekonomičnosti, poštujući javni interes cijelog uslužnog područja te osiguravajući kvalitetu usluge i uštede troškova isporučitelja. U tom slučaju u konvenciji o kooperaciji općina provincija se određuje kao subjekt koji će koordinirati izvršavanje usluga izmedu više isporučitelja.

10 Tako je na nacionalnoj razini broj upravitelja sustavom po pojedinom uslužnom području 1,7 , u regijama na sjeveru taj se broj povećava na 2,3, a u središnjem dijelu i na jugu Italije iznosi 1,1 . 
istovremeno obavljaju djelatnost i drugi isporučitelji. Cilj integriranog upravljanja vodnim uslugama jednim isporučiteljem u Italiji još uvijek nije ostvaren te je potrebno učiniti još mnogo kako bi se obavljanje vodnih usluga integriralo u aktivnostima jednog upravitelja sustava na uslužnom području, naročito s obzirom na integraciju usluge javne odvodnje otpadnih voda, koju je zbog naslijeđene teritorijalne organizacije na pojedinim područjima teško integrirati u sustav. Pa ipak, u početku reforme 1999. u Italiji je evidentirano 7.826 isporučitelja vodnih usluga, krajem 2007. taj je broj praktično prepolovljen na 3.986 isporučitelja, od kojih je 112 bilo upravitelja sustava integriranih vodnih usluga. ${ }^{11}$

U Hrvatskoj de lege lata djelatnost vodnih usluga mogu obavljati isključivo javni isporučitelji, tj. pravne osobe u kojima su osnivači jedinice lokalne samouprave ili trgovačka društva kojima su osnivači jedinice lokalne samouprave (tzv. tvrtke kćeri). De lege ferenda, PZVU (čl. 23.) predlaže da upravitelj sustava na svakom uslužnom području bude ustanova kojom upravlja osnivačko vijeće koje čine po jedan gradonačelnik i općinski načelnik iz svakog grada odnosno općine s uslužnog područja, jedan predstavnik radnika te jedan predstavnik države kojeg imenuje i razrješuje ministar. Predlaže se da ukupan broj glasova (nedjeljivi glasovi) u osnivačkom vijeću bude istovjetan broju stanovnika na uslužnom području, prema zadnjem popisu stanovništva uvećan $10 \%$ te za broj radnika javnog isporučitelja vodnih usluga, s time da JLS ima onoliko glasova koliko ima stanovnika na području JLS, država ima 10\% glasova ukupnog broja stanovnika na uslužnom području, a radnici javnog isporučitelja vodnih usluga imaju onoliko glasova koliko ima zaposlenih u javnom isporučitelju vodne usluge, te da vijeće odlučuje običnom većinom nefiksnih glasova nazočnih na sjednici osnivačkog vijeća, osim kad je izričito propisano da odlučuje dvostrukom većinom. Ovaj je prijedlog u javnoj raspravi izazvao mnoge prijepore, naročito s obzirom na predložen udio države u upravljačkom vijeću koji se percipira u javnosti kao jedan oblik centralizacije, te se može očekivati da će do konačnog teksta zakona biti predložena i drugačija rješenja.

\subsection{Integracija troškova vodnih usluga na uslužnom području}

Tarifa vodnih usluga određena je kvalitetom vodnih resursa i kvalitetom isporučenih usluga, troškovima izgradnje i održavanja infrastrukturnih

11 ISTAT, La gestione dei servizi idrici in Italia al 31 dicembre 2007. 
objekata te troškovima upravitelja sustava i temelji se na punom povratu troškova investicija i troškova isporuke usluga na uslužnom području prema načelu onečišćivač plaća. Tarifa može predviđati pogodnosti za uporabu vode u domaćinstvu i za određene socijalno ugrožene kategorije stanovnika za utvrđene raspone dohotka.

Odlučivanje o cijenama vodnih usluga i planiranje razvoja infrastrukturnog sustava osnovna su obilježja upravljanja vodnim uslugama u lokalnim jedinicama. Međutim, na uslužnom području plan razvoja infrastrukture mora obuhvatiti uslužno područje u cjelini, pa stoga i tarifa vodnih usluga obuhvaća prosječne troškove vodnih usluga, ne više samo na području lokalne jedinice, već na uslužnom području u cjelini. Ključno je pitanje kako postići suglasnost velikog broja lokalnih jedinica na uslužnom području o tim pitanjima jer isporučitelj objedinjava isporuku vodnih usluga za velik broj lokalnih jedinica, pa se utjecaj pojedinih, naročito manjih, lokalnih jedinica u procesu odlučivanja o tarifama i planiranju razvoja infrastrukture može ponekad disperzirati i minimalizirati.

Jedinstvena tarifa cijena vodnih usluga na uslužnom području jedna je od temeljnih odrednica sustava integriranih vodnih usluga, ali i najsloženijih u provedbi. Primjerice, u Italiji ni nakon niza godina od uvođenja reforme u ovom sektoru (1994.) taj cilj nije postignut u cijelosti. U 66 uslužnih područja koja su funkcionirala u 2008. godini u primjeni je bilo 300 različitih tarifnih sustava koji su se međusobno značajno razlikovali u osnovnim elementima, odnosno prosječno 4,54 tarifna sustava po uslužnom području. ${ }^{12} \mathrm{U}$ uslužnom području Lazio Roma-Centrale tek je krajem 2010. prihvaćen novi tarifni sustav jedinstven za sve općine koje se nalaze u sustavu upravitelja sustavom, dok je do tada svaka općina na uslužnom području imala vlastiti tarifni sustav, tj. u primjeni je bilo oko 70 tarifnih sustava. Novi tarifni sustav prihvaćen je radi pokrivanja troškova nužnih investicija u narednim godinama te su ti troškovi raspodijeljeni ravnomjerno na cijelo uslužno područje, odnosno na općine koje pripadaju tom uslužnom području i koje su povjerile obavljanje vodnih usluga upravitelju sustava. ${ }^{13}$ Općine koje obavljanje vodnih usluga nisu povjerile upravitelju sustava imale su istovremeno svoje tarife, ali su se te tarife imale primijeniti na one općine koje su se tijekom 2011. odlučile obavljanje vodnih usluga povjeriti upravitelju sustava.

12 Podacima za 66 uslužnih područja obuhvaćeno je 38.373 .328 stanovnika (stanovnici koji nisu obuhvaćeni 19.633.434) te je procijenjeno da je uzorak reprezentativan.

13 Tarifa unica del Servizio Idrico Integrato per i servizi comunali trasferiti ad A.C.E.A ATO 2 nel 2003-2009, Valori effetivi per l' anno 2011. B.U.R.L. 
U Hrvatskoj PZVU promovira načelo jedinstvene cijene vodnih usluga za istu kategoriju korisnika na uslužnom području (čl. 47/3. PZVU), a odluku donosi osnivačko vijeće javnog isporučitelja.

\section{Vertikalna integracija}

Integralno upravljanje vodnim uslugama pretpostavlja vertikalnu integraciju sustava na razini središnje države. Takvo se upravljanje često percipira kao oduzimanje ovlasti lokalnim jedinicama i jedan od oblika centralizacije lokalnih poslova. No, funkcija vertikalne integracije je nadzor, koordinacija i održavanje cjeline sustava vodnih usluga na razini države. Verikalna integracija vodnih usluga pretpostavlja formiranje organizacijski, funkcionalno, personalno, financijski i pravno nezavisnog središnjeg državnog regulacijskog tijela za nadzor i praćenje stanja u sektoru vodnih usluga i važan je instrument u objedinjavanju sustava vodnih usluga. $U$ nadzoru cijena usluga regulacijsko tijelo u pravilu ima ovlast odrediti maksimalne cijene (tzv. price cut) koje isporučitelji mogu primjenjivati u određenom razdoblju. Te regulacijske mjere u pravilu su učinkovito sredstvo nadzora i ex ante sprječavanja potencijalnih povreda pravila o zaštiti potrošača i zaštiti tržišnog natjecanja, bez potrebe ex post djelovanja nadležnih tijela (Popović, 2008, str. 706). ${ }^{14}$

Središnje državno tijelo koje objedinjava funkcioniranje sustava vodnih usluga u Italiji je Comitato per la vigilanza sull' uso delle risorse idrice, koji je osnovan pri Ministarstvu okoliša i zaštite tla i mora, s ciljem jamstva načela efikasnosti, efektivnosti i ekonomičnosti u upravljanju vodnim resursima, s posebnom ulogom u ispravnom određivanju i primjeni tarifa i

14 V. rješenje Agencije za zaštitu tržišnog natjecanja, klasa UP/-030-02/2004-01/66, urbroj 580-02-05-41-42 od 20. listopada 2005. (NN 132/05). Iz obrazloženja: »Agencija za zaštitu tržišnog natjecanja u upravnom postupku utvrđivanja sprječavanja, ograničavanja ili narušavanja tržišnog natjecanja zlouporabom vladajućeg položaja od strane poduzetnika temeljem odluke Vijeća za zaštitu tržišnog natjecanja, utvrdila je da je poduzetnik P. d.o.o. od 12. studenoga 2003. nadalje narušavao tržišno natjecanje zlouporabom vladajućeg položaja na mjerodavnom tržištu opskrbe vodom kućanstava putem vodovodne mreže i odvodnje i pročišćavanja otpadnih voda kućanstava na otoku K., i to izravnim nametanjem nepravednih prodajnih cijena usluga. Takvim načinom određivanja cijena potrošači su radi postizanja financijski povoljnijih uvjeta upućeni na špekulantsko ponašanje vezano uz potrošnju vode, odnosno na neracionalnu i beskorisnu potrošnju vode jer u tom slučaju plaćaju niži iznos naknade nego kada bi se vodili logikom razumne i dostatne potrošnje.« 
zaštite interesa korisnika ${ }^{15}$ te, inter alia, ima ove nadležnosti: a) predlaže odluku o načinu (metodi) izračuna tarifa integriranog sustava vodnih usluga te periodičnih izmjena tarife, koju dostavlja Ministarstvu okoliša i zaštite tla i mora Republike Italije, koje ga prihvaća nakon pribavljenog mišljenja Stalne konferencije za odnose između države, regija i autonomnih provincija Trento i Bolzano, b) potvrđuje planove uslužnih područja, izražavajući primjedbe, nalaze i zahtjeve prema tehničkim elementima i o potrebama izmjene ugovornih klauzula i akata kojima je uređen odnos između uprave uslužnog područja i isporučitelja usluga, naročito kada to zahtijevaju opravdane potrebe korisnika, c) predlaže odlukom jedan ili više oblika konvencije kojom se uređuje odnos između uprave optimalnog područja i isporučitelja usluga, koju dostavlja Ministarstvu okoliša i zaštite tla i mora, koje ga prihvaća nakon pribavljenog mišljenja Stalne konferencije za odnose između države, regija i autonomnih provincija Trento i Bolzano, d) donosi direktive za računovodstvenu transparentnost upravljanja i procjenjuje troškove pojedinih davanja, e) određuje minimalne razine kvalitete usluga, nakon pribavljenog mišljenja regija, isporučitelja i udruga korisnika usluga, f) nadzire načine isporuke usluga prikupljanjem informacija $\mathrm{i}$ isprava od isporučitelja radi utvrđivanja kritičnih situacija $\mathrm{i}$ funkcionalnih nepravilnosti $u$ isporuci vodnih usluga, g) štiti i jamči prava korisnicima donošenjem pravila koja osiguravaju jednako postupanje kako bi se osigurala jednakost u postupanju prema korisnicima, kontinuitet isporuke usluga i periodično provjerila kvaliteta i efektivnost usluga, e) donosi mišljenja o specifičnim problemima s obzirom na kvalitetu usluga i zaštitu potrošača, prema zahtjevu Ministarstva okoliša i zaštite tla i mora, regija, lokalnih jedinica, uprava uslužnih područja, udruga potrošača i pojedinih korisnika integriranog sustava vodnih usluga; radi izvršenja tih zadaća Komitet obavlja sektorska istraživanja i studije, 1) podnosi parlamentu godišnji izvještaj o stanju u sektoru vodnih usluga.

Agencija za zaštitu okoliša Slovenije obavlja inter alia sljedeće aktivnosti: a) poticanje održivog korištenja voda, b) ekonomsku procjenu vode (uključujući troškove vode, opterećenja, zaštite i regulacije u cijeni vode), c) sudjelovanje javnosti u donošenju planova upravljanja vodama, d) provodi postupke, čuva račun za vodu, pristojbe i prati plaćanja, e) prati i obrađuje izvješća o praćenju otpadnih voda, f) priprema provedbene programe u području prenošenja pravne stečevine EU, g) obavlja stručne poslove $u$ provedbi međunarodnih obveza.

15 Art. 161. Codice d'Ambiente Dlgs 152/2006. 
U Hrvatskoj središnje državno tijelo za nadzor i praćenje stanja u sektoru vodnih usluga je Vijeće za vodne usluge, koje se osniva radi osiguranja zakonitosti u području određivanja cijene vodnih usluga, naknade za razvoj i naknade za priključenje (čl. 216.-219. ZoV). Vijeće ima sljedeće ovlasti: 1. predlaže Vladi Republike Hrvatske da uredbom propisuje najnižu osnovnu cijenu vodnih usluga i vrste troškova koje cijena vodnih usluga pokriva, 2. predlaže Vladi Republike Hrvatske propis o najvišem iznosu naknade za priključenje iz zakona kojim se uređuje financiranje vodnoga gospodarstva, 3. nadzire zakonitost odluke o cijeni vodnih usluga, 4. nadzire zakonitost odluke o naknadi za razvoj iz zakona kojim se uređuje financiranje vodnoga gospodarstva, 5. nadzire zakonitost odluke o naknadi za priključenje iz zakona kojim se uređuje financiranje vodnoga gospodarstva i 6. nadzire zakonitost određivanja cijene vode isporučitelja vodne usluge koji isporučuje vodu namijenjenu ljudskoj potrošnji drugom isporučitelju vodne usluge. U postupku nadzora zakonitosti odluke o cijeni vodnih usluga, odluke o naknadi za razvoj iz zakona kojim se uređuje financiranje vodnoga gospodarstva i odluke o naknadi za priključenje iz zakona kojim se uređuje financiranje vodnoga gospodarstva, Vijeće je ovlašteno rješenjem u upravnom postupku obustaviti od izvršenja nezakonitu odluku te donijeti privremenu mjeru i odrediti cijenu vode do pravomoćne odluke suda. Protiv navedenih odluka Vijeća nije dopuštena žalba, ali je dopušten upravni spor koji se rješava u hitnom postupku.

\section{Zaključak}

Zahtjevi za integralnim upravljanjem opskrbom vodom za piće i odvodnjom otpadnih voda kao esencijalnim uslugama za građane posljedica su promjena krajem 20. i početkom 21. stoljeća koje se iskazuju u potrebi očuvanja vodnih resursa u okolišu i njihovom racionalnom korištenju. To zahtijeva uporabu novih, složenih i skupih tehnologija za preradu sirove vode do kvalitete vode za piće i za pročišćavanje sanitarnih otpadnih voda radi dostizanja visokih standarda kvalitete vode za piće i standarda prihvatljivog sadržaja otpadnih voda koje se upuštaju u okoliš. Tim će se objektivnim okolnostima morati prilagoditi i sustavi lokalnih jedinica koji su u europskim državama (pa tako i u Hrvatskoj) zasnovani pretežno na teritorijalno manjim lokalnim jedinicama čija su područja određena povijesnim granicama iz prethodnih stoljeća i tadašnjim uvjetima obavljanja vodnih usluga s dostupnošću resursa vode i manjom koncentracijom stanovništva. 
Moramo, međutim, prihvatiti da je 20. stoljeće kao stoljeće svekolikog tehnološkog napretka, pronalaska novih tehnoloških procesa i materijala donijelo mnoge pogodnosti za svakodnevni život stanovnika, ali i generiralo pogubne utjecaje na prirodne resurse i okoliš (voda, tlo, zrak). Zahtjevi održivog razvoja radi zaštite i očuvanje okoliša u 21. stoljeću primorat će, volens-nolens, lokalne jedinice na drugačije ponašanje, međusobno povezivanje i udruživanje, suradnju i zajedničko obavljanje djelatnosti iz njihove nadležnosti, najprije u onim djelatnostima njihova samoupravnog djelokruga koje imaju značajan utjecaj na okoliš, kao što su opskrba vodom za piće i odvodnja sanitarnih otpadnih voda. Percepcija tog procesa kao prisilne centralizacije lokalnih poslova zbog nepovjerenja središnje države u lokalne jedinice daleko je od istine.

Promjene uvjeta obavljanja vodnih usluga kao primarno usluga iz djelokruga lokalnih jedinica može se prihvatiti kao jedan od elemenata teritorijalne integracije i prevladavanja fragmentiranosti sustava lokalne samouprave koji postaje kočnica budućem razvoju. Iako se teritorijalna integracija lokalnih jedinica na uslužnom području zbog prirodne veličine područja (tj. vodni podsliv) ne mora dogoditi tako da pojedino uslužno područje postane jedna lokalna jedinica, manji broj većih lokalnih jedinica na uslužnom području (primjerice 5-10 lokalnih jedinica) zasigurno bi ojačao procese odlučivanja i efikasnost u upravljanju vodnim uslugama na tom području.

Može se zaključiti da će tehnološke potrebe funkcije isporuke vodnih usluga kao usluga kojima se zadovoljavaju esencijalne životne potrebe stanovništva u uvjetima pogoršanja dostupnosti vodnih resursa u budućnosti biti značajan faktor u preslaganju područja i granica lokalnih jedinica.

\section{Literatura}

Jùnch-Clausen, T., \& Fugl, J. (2001). Firming up the Conceptual Basis of Integrated Water Resources Management. International Journal Water Resources Development, 17(4), 501-510, http://www.researchgate.net/ publication/248997329_Firming_up_the_Conceptual_Basis_of_Integrated_ Water_Resources_Management

Fitzmaurice, M. (2007). The Human Right to Water. Fordham Environmental Law Review, 18, 537-587".

Mikoš, M. (2011). Integralno upravljanje voda in regionalizacija Republike Slovenije. Geodetski vjesnik, 55(3), 518-529.

Nacionalni program (2004). Nacionalni program upravlianja vodama Republike Slovenije. Preuzeto s http://www.npvo.si/osnutek/43_kakovost_zivljenja.pdf 
Plan, (2010). Plan provedbe vodno-komunalnib direktiva u Republici Hrvatskoj. Preuzeto s http://www.voda.hr/ppvkd/Dokumenti/PLAN\%20PROVEDBE\%20 VODNOKOMUNALNIH\%20DIREKTIVA\%20-\%20HRVATSKI.pdf

Popović, N. (2008). Regulacija cijena u vodoopskrbnoj djelatnosti u Republici Hrvatskoj. Hrvatska javna uprava, 8(3), 689-719.

Sarvan, D. (2014). Pravo na vodu kao povijesno nasljeđe čovječanstva. Hrvatske vode, 22(88), 131-140.

Sarvan, D. (2014). Efekti privatizacije vodnih usluga. Hrvatska i komparativna javna uprava, 14(3), 612-638.

Perko-Šeparović, I., \& Hrženjak, J. (1998). Organizacija teritorija i samoupravljanje. U: Hrestomatija upravne znanosti, svezak II. (str. 65-123). Zagreb, Hrvatska: Pravni fakultet.

UNESCO (2009). World Water Development Report 3 - Water in a Changing World. Paris, France. Preuzeto s www.unesco.org/water/wwap/wwdr

UNESCO (2012). World Water Development Report 4 - Managing Water Under Uncentrainty and Risks. Paris, France. Preuzeto s http://www.unwater.org/publications/publications-detail/en/c/202715/

UNDP (2006). Human Development Report - Beyond scarcity: Power, poverty and the global water crisis. New York, USA. Preuzeto s http://hdr.undp.org/sites/ default/files/reports/267/hdr06-complete.pdf b 13

Van Ginneken, M., \& Kingdom, B. (2008). Key Topics in Public Water Utility Reform. Water Working Note, No. 17 (str. 1-53). New York, SAD: Water Sector Board of the Sustainable Development Network of the World Bank Group.

\section{Propisi}

Codice d' Ambiente Repubblica Italia, Dlgs 152/2006, G.U. 14.04.2006, http:// www.altalex.com/?idnot=33891

ISTAT, La gestione dei servizi idrici in Italia al 31 dicembre 2007, http://www. istat.it/it/

Legge Repubblica Italia No. 36/94 , (Legge Galli), http://www.ambientediritto.it/ Legislazione/ACQUA/Legge\%2094\%20n.36.htm

Relazione Comitato per la vigilanza sull' uso delle risorse idrice all Parlamento Italiano per anno 2008

Rješenje Agencije za zaštitu tržišnog natjecanja, klasa UP/-030-02/2004-01/66, 20. listopada 2005., NN 132/05

Uredba o uslužnim područjima, NN 67/14

Tarifa unica del Servizio Idrico Integrato per i servizi comunali trasferiti ad A.C.E.A ATO 2 nel 2003-2009, Valori effetivi per l' anno 2011., B.U.R.L.

Testo Unico Enti Locali, agg. al 21.07.2014, http://www.altalex.com/index.php?idnot $=1091$

Zakon o vodama, NN 153/09, 63/11, 130/11, 56/13 i 14/14 


\section{WATER MANAGEMENT AS AN ISSUE IN THE TERRITORIAL INTEGRATION OF LOCAL UNITS}

\section{Summary}

Since the beginning of the 21st century, changes in the availability of water resources and protection requirements have brought about changes in the sphere of water services management. Once a traditionally local responsibility, it has moved beyond being merely a communal service. Changes in water services management are reflected in the integration of supplying drinking water and disposing of wastewater into a single service. This is based on the principle of managing the water supply from the source to the user, and from the user up to the point of discharge into the environment in an area which is found to be most functional, and is formed on the basis of the bydrogeological territory of sub-drainage basins, which follow the natural boundaries of drainage divides - these are called service areas. Such service areas generally comprise a large number of local units, which is why demands for efficient water services management will have an impact on the territorial integration of local units in individual service areas.

Keywords: water services, second-tier service, local units, service area, sub-drainage basin 